\title{
ANALISIS VARIABEL MAKROEKONOMI TERHADAP KINERJA REKSADANA CAMPURAN
}

\author{
Augustina Kurniasih dan Leonardo David Yuliandy Johannes \\ Universitas Mercu Buana Jakarta \\ Email: aldo_ferdiant@yahoo.com dan augustina.kurniasih@gmail.com
}

\begin{abstract}
Nowadays investment instruments are growing. One of the investment instruments is mutual fund. Indonesian macroeconomic conditions affected the performance of investments, including on mutual funds. One type of mutual fund is balance mutual funds. This study aims to examine and analyze the effect of stock index returns, return of USD exchange rate, return of JIBOR Interest Rate, and return of government bonds of Indonesia to the performance of balance mutual funds. Observation period is one year (2012), using daily data. Total balance mutual funds in IDX are 120, which meets the criteria of the sample were 86. Method used to answer the research problem is multiple linear regressions. It found that macroeconomic factors that significantly influence the performance of balance mutual funds are returns JCI and JIBOR interest rate return.
\end{abstract}

Keywords: JCI Return, USD Exchange Rate Return, JIBOR Interest Rate Return, Indonesian Government Bond Index Return, Ballance Mutual Funds

\begin{abstract}
Abstrak: Saat ini semakin banyak tersedia pilihan instrumen investasi. Salah satu instrumen investasi adalah reksadana. Kondisi makroekonomi Indonesia mempengaruhi kinerja investasi, termasuk investasi reksadana. Salah satu jenis reksadana adalah reksadana campuran. Penelitian ini bertujuan menguji dan menganalisis pengaruh return IHSG, return Kurs USD, return JIBOR Interest Rate dan return Obligasi Pemerintah Indonesia terhadap kinerja reksadana campuran. Periode penelitian adalah selama satu tahun (2012), menggunakan data harian. Total reksadana campuran di BEI berjumlah 120, yang memenuhi kriteria menjadi sampel sebanyak 86 . Metode yang digunakan untuk menjawab permasalahan penelitian adalah regresi linier berganda. Ditemukan bahwa faktor makroekonomi yang berpengaruh signifikan terhadap return reksadana campuran adalah return IHSG dan Suku Bunga JIBOR.
\end{abstract}

Kata kunci: return IHSG, return JIBOR, return kurs, return IGBX, return reksadana campuran

\section{PENDAHULUAN}

Reksadana merupakan salah satu alternatif investasi bagi masyarakat pemodal. Reksadana dirancang sebagai sarana untuk menghimpun dana dari masyarakat, khususnya pemodal kecil, dan pemodal yang tidak memiliki banyak waktu dan keahlian untuk menghitung risiko atas investasi mereka. 
Penghitungan hasil investasi di reksadana relatif mudah, yaitu dengan cara menghitung jumlah unit penyertaan reksadana yang dimiliki dikalikan dengan selisih dari harga Nilai Aktiva Bersih (NAB) jual dengan harga NAB beli reksadana (Grevina, 2013).

Nilai Aktiva Bersih (NAB) merupakan salah satu tolok ukur dalam memantau hasil investasi atas reksadana. NAB/unit penyertaan adalah harga wajar dari portofolio suatu reksadana setelah dikurangi biaya operasional kemudian dibagi jumlah unit penyertaan yang telah beredar (dimiliki investor) pada suatu periode. NAB dilaporkan Manajer Investasi ke Bank Kustodian. Bank Kustodian adalah lembaga keuangan yang khusus menangani dan mencatat aset-aset Manajer Investasi untuk kemudian diumumkan ke publik melalui surat kabar setiap hari.

Ada empat jenis reksadana di Indonesia yaitu Reksadana Pasar Uang, Reksadana Pendapatan Tetap, Reksadana Campuran, dan Reksadana Saham (Bank Indonesia, 2013). Reksadana Saham dan Reksadana Campuran memiliki komposisi saham lebih besar apabila dibandingkan dengan Reksadana Pendapatan Tetap. Adapun saham sebagai salah satu sarana investasi memiliki imbal hasil (return) yang relatif tinggi, dan di sisi lain mengandung risiko investasi yang juga relatif tinggi.

Data pada Tabel 1 berikut ini menunjukkan market share dan return dari beberapa jenis reksadana. Total NAB Kelolaan per tahun 2013 adalah Rp. 183,25 Trilyun dan 110,69 Milyar Unit. Mengacu total NAB Kelolaam tersebut Reksadana Campuran memiliki share Rp. 21,58 Trilyun. Share terbesar adalah pada Reksadana Saham Tetap, yaitu Rp. 69,73 Trilyun. Namun demikian, di antara ketiga jenis reksadana, Reksadana Campuran mampu memberikan return dalam 1 (satu) tahun terbesar, yaitu mencapai $26,41 \%$.

Tabel 1. Market Share dan Return Reksadana

\begin{tabular}{lcc}
\hline \multicolumn{1}{c}{ Jenis Reksadana } & Market Share (Trilyun)* & Return per tahun ** \\
\hline RD Saham & 69,73 & $20,38 \%$ \\
RD Campuran & 21,58 & $26,41 \%$ \\
RD Pendapatan Tetap & 33,02 & $10,63 \%$ \\
\hline
\end{tabular}

Sumber: * www.bapepam.go.id/reksadana, 2013

** www.infovesta.com, 2013

Reksadana Campuran (RDC) merupakan reksadana yang umumnya berinvestasi pada saham, obligasi, dan instrumen pasar uang sekaligus. Saat volatilitas di pasar tinggi, RDC dapat dijadikan isntrumen investasi yang tepat karena memiliki fleksibilitas pada alokasi asetnya sehingga dapat secara langsung memberikan investasi yang terdiversifikasi kepada investor (Pertiwi, 2013).

Investasi RDC dialokasikan di efek saham dan efek obligasi, dimana masing-masing efek tidak lebih dari $80 \%$. RDC merupakan pilihan reksadan yang dapat memberikan keuntungan maksimal pada tahun 2010. Komposisi investasi di saham dan pendapatan tetap akan sangat menguntungkan, karena adanya diversifikasi dalam investasi ini, sehingga jika salah satu efek mengalami kerugian, maka efek yang lain akan mengkompensasi (Silitonga, 2010)

Ross (1976) mengembangkan Arbitrage Pricing Theory (APT) yang mengaitkan variable makroekonomi dengan return pasar modal. Teori ini merupakan perluasan dari Capital Assets Pricing Model (CAPM). Pendekatan CAPM menyatakan hanya ada satu variabel bebas, yaitu risk premium pasar, yang mempengaruhi return saham, sementara 
pendekatan APT menyatakan return investasi di pasar modal juga dipengaruhi variabel makroekonomi.

Perubahan harga saham dipengaruhi oleh beberapa faktor. Sebagaimana dijelaskan Bodie, et al, (2012) bahwa terdapat tujuh faktor yang mempengaruhi perubahan harga saham yaitu: (1) gross domestic product (GDP), (2) inflasi, (3) tingkat pengangguran, (4) suku bunga, (5) nilai tukar, (6) transaksi berjalan, (7) defisit anggaran.

Roll dan Ross (1986) meneliti pengaruh faktor ekonomi yang diwakili oleh pertumbuhan industri, inflasi, tingkat suku bunga, pertumbuhan konsumsi, dan pertumbuhan harga minyak. Faktor ekonomi tersebut digunakan untuk menjelaskan pergerakan indeks harga saham di NYSE tahun 1958-1984. Hasil penelitian mereka menunjukkan bahwa variable-variabel yang digunakan tersebut dapat menjelaskan imbal hasil (return) saham yang diharapkan secara signifikan.

Memperhatikan kenyataan bahwa kondisi makrekonomi mempengaruhi kegiatan ekonomi di suatu Negara, termasuk kegiatan investasi yang dilakukan masyarakat maka sebaiknya investor mengetahui dan memahami kondisi makroekonomi ketika akan membuat keputusan investas, termasuk investasi di pasar modal. Reksadana merupakan salah satu instrument investasi di pasar modal.

Di Indonesia beberapa penelitian terdahulu mengenai reksadana telah dilakukan namun jarang ditemukan yang spesifik terhadap reksadana campuran. Penelitian Pasha (2005) dan Yoedistira (2007) dilakukan terhadap reksadana secara umum. Penelitian Tamsul (2005); Permata (2009); Rahmawati (2009); Wibowo, (2011), dan Permatasari (2014) meneliti mengenai reksadana pendapatan tetap. Pasaribu dan Kowanda (2014) meneliti reksadana saham. Selanjutnya Sembiring (2007) dan Ulinnuha (2014) meneliti reksadana campuran.

Para peneliti terdahulu telah menganalisis pengaruh berbagai variabel makroekonomi terhadap perkembangan atau return reksadana. Variabel makro ekonomi tersebut antara lain IHSG (Kurnia, Pasha, Hamdan, Tamsul, Pasaribu dan Kowanda), Kurs (Permata, Yoedistira, Wibowo, dan Permatasari), SBI (Kurnia, Hamdan, Permata, Yoedistira, Wibowo, serta Pasaribu dan Kowanda), Deposito (Hamdan dan Tamsul), Inflasi (Hamdan, Permata, Wibowo, serta Pasaribu dan Kowanda), Pertumbuhan Ekonomi (Hamdan), Indeks Obligasi (Permata), Harga Minyak Bumi Minyak Mentah (Permata, Rahmawati, dan Wibowo), Produk Domestik Bruto (Yoedistira), dan Harga Emas (Wibowo). Hasil penelitian menunjukkan masih terdapat perbedaan pengaruh dari variable makroekonomi tesebut terhadap reksadana.

SBI merupakan ukuran tingkat suku bunga di pasar uang. Selain SBI, suku bunga pasar uang juga bisa diwakili oleh suku bunga Jakarta Interbank Offered Rate (JIBOR). Selain NAB, tolok ukur dalam memantau hasil investasi atas reksadana dapat dihitung dari return yang diperoleh. Return merupakan selisih antara nilai saat ini dengan nilai periode sebelumnya. Penelitian ini ingin menguji dan menganalisis pengaruh return IHSG, return Kurs USD, return Suku Bunga JIBOR, dan return Indeks Obligasi Negara terhadap Kinerja Reksadana Campuran. Selanjutnya juga ingin diketahui variabel yang memiliki pengaruh paling besar terhadap Kinerja Reksadana Campuran.

\section{KAJIAN TEORI}

Ross (1976) mengajukan pendekatan multifaktor untuk menjelaskan asset pricing. Menurut Ross faktor-faktor utama yang mempengaruhi return saham adalah beberapa 
kekuatan ekonomi seperti (1) pergerakan yang tidak diantisipasi dari risk-premium, (2) perubahan ekspektasi tingkat produksi industry, (3) inflasi yang tidak terduga, dan (4) pergerakan stuktur tingkat bunga yang tidak terduga.

Undang-undang tentang Pasar Modal Indonesia No. 8 tahun 1995, pasal 1 ayat (27), mendefinisikan Reksa Dana adalah wadah yang dipergunakan untuk menghimpun dana dari masyarakat pemodal untuk selanjutnya diinvestasikan dalam portofolio efek oleh manajer investasi.

Dilihat dari portfolio investasinya, Reksa Dana dapat dibedakan menjadi (BEI, 2010):

1) Reksa Dana Pasar Uang (Money Market Funds). Reksa Dana jenis ini hanya melakukan investasi pada Efek bersifat Utang dengan jatuh tempo kurang dari 1 (satu) tahun. Tujuannya adalah untuk menjaga likuiditas dan pemeliharaan modal.

2) Reksa Dana Pendapatan Tetap (Fixed Income Funds). Reksa Dana jenis ini melakukan investasi sekurang-kurangnya $80 \%$ dari aktivanya dalam bentuk Efek bersifat Utang. Reksa Dana ini memiliki risiko yang relatif lebih besar dari Reksa Dana Pasar Uang. Tujuannya adalah untuk menghasilkan tingkat pengembalian yang stabil.

3) Reksa Dana Saham (Equity Funds). Reksa dana yang melakukan investasi sekurangkurangnya $80 \%$ dari aktivanya dalam bentuk Efek bersifat Ekuitas. Karena investasinya dilakukan pada saham, maka risikonya lebih tinggi dari dua jenis Reksa Dana sebelumnya namun menghasilkan tingkat pengembalian yang tinggi.

4) Reksa Dana Campuran (Discretionary Funds). Reksa Dana jenis ini melakukan investasi dalam Efek bersifat Ekuitas dan Efek bersifat Utang.

Investor yang melakukan investasi, baik di pasar modal maupun pasar uang, mengharapkan imbal hasil (return) atas investasinya. Menurut Tandelilin (2001) return merupakan salah satu faktor yang memotivasi investor berinteraksi dan juga merupakan imbalan atas keberanian investor menanggung risiko atas investasi yang dilakukannya. Sedangkan Pratomo dan Ubaidillah (2004) menyatakan bahwa return merupakan suatu imbalan, pengembalian atau sejumlah hasil yang akan diperoleh investor dari investasinya, dimana dalam hal ini adalah masa yang akan datang.

$\mathrm{NAB} /$ unit merupakan harga beli per unit penyertaan yang dibayarkan investor yang berinvestasi di reksadana. Apabila investor akan mencairkan investasi reksadananya, maka $\mathrm{NAB} /$ unit menjadi harga jual per unit penyertaan. Menurut Alwi (2005) Nilai Aktiva Bersih (NAB) adalah jumlah aktiva setelah dikurangi kewajiban-kewajiban yang ada. Sementara NAB/unit adalah jumlah NAB dibagi dengan jumlah jumlah unit penyertaan yang beredar (outstanding). Dengan demikian NAB/unit menjadi indikator return dalam investasi reksadana.

Keberanian investor melakukan investasi dipengaruhi oleh keberanian menghadapi risiko. Risk premium adalah rata-rata tingkat keuntungan setelah dikoreksi oleh tingkat keuntungan aset bebas risiko. Investasi dalam saham selalu menanggung risiko yang lebih besar daripada deposito, sehingga investor akan mengharapkan return saham di atas risk free atau mengharapkan market premium sebagai kompensasi atas kemungkinan menanggung market risk dan semua investor berkeinginan membentuk portfolio yang memiliki karakteristik sama dengan karakteristik portfolio pasar. Risk premium pada individu aset akan proporsional terhadap risiko premium pada portfolio pasar.

Risk premium pasar ditengarai oleh pergerakan indeks harga saham secara keseluruhan di pasar modal. Di Indonesia indeks harga saham di pasar modal dikenal 
sebagai Indeks Harga Saham Gabungan (IHSG). IHSG di Indonesia diperkenalkan pertama kali pada tanggal 1 April 1983. IHSG merupakan indikator pergerakan harga saham di Bursa Efek Indonesia (BEI). Indeks ini mencakup pergerakan harga seluruh saham biasa dan saham preferen yang tercatat di BEI. Hari Dasar untuk perhitungan IHSG adalah tanggal 10 Agustus 1982. Tanggal tersebut, Indeks ditetapkan dengan Nilai Dasar 100 dan saham tercatat pada saat itu berjumlah 13 saham

Indeks Harga Saham (IHS) merupakan ringkasan dari pengaruh simultan dan kompleks dari berbagai macam variabel yang berpengaruh, terutama tentang kejadiankejadian ekonomi (Halim, 2003). Saat ini IHS juga menampung kejadian-kejadian sosial, politik, dan keamanan. Dengan demikian IHS dapat dijadikan barometer kesehatan ekonomi suatu negara dan sebagai dasar melakukan analisis statistik atas kondisi pasar terakhir (current market). IHS di BEI disebut sebagai IHSG. Harga saham yang digunakan dalam menghitung IHSG adalah harga saham di pasar regular yang didasarkan pada harga yang terjadi berdasarkan sistem lelang.

Indonesia merupakan Negara terbuka, yang melakukan hubungan politik dan ekonomi dengan Negara lain, meskipun dalam volume transaksi relative kecil sehingga disebut sebagai small opened economy atau emerging market. Menurut Bhattacharya et al (2013) negara-negara yang tergolong dalam emerging market menunjukkan kisaran yang besar dalam hal degree of trade openness relative to financial openness. Disebutkan bahwa Mexico, Turki, dan Indonesia serupa dengan India dalam ukuran openness in trade than financial flows. Tidak heran jika arus dana di pasar modal Indonesia, lebih dari 60 persen dikuasai oleh investor atau pemodal asing (Departemen Keuangan RI, 2008). Selain itu terbukanya perdagangan antar negara menyebabkan kurs nilai tukar mata uang antar Negara juga menjadi penting. Nilai tukar adalah tingkat harga yang disepakati penduduk dua negara yang melakukan transaksi perdagangan internasional.

Nilai tukar mata uang asing (the exchange rate) atau nilai kurs menyatakan hubungan nilai di antara satu uang asing dan mata uang yang berlaku dalam negeri di suatu Negara. Menurut Dominic (2007), kurs didefinisikan sebagai harga mata uang luar negeri dalam satuan mata uang dalam negeri. Apabila kondisi ekonomi negara berubah, maka nilai tukarnya pun akan berubah secara substansial. Penurunan nilai suatu mata uang disebut depresiasi dan kenaikannya disebut apresiasi. Apabila "S" adalah nilai spot rate dan "St-1" adalah nlai tukar mata uang waktu sebelumnya, maka prosentase perubahan nilai tukar terhadap mata uang asing tersebut adalah S-St-1/St-1 (Madura 2000). Jika presentase perubahannya positif disebut apresiasi dan sebaliknya apabila nilai persentasenya negatif disebut depresiasi.

Teori ekonomi klasik membuat hipotesis bahwa harga saham dan nilai tukar berkaitan. Pendekatan pertama dicakup dalam model "inflow oriented" yang membuat postulasi bahwa pergerakan nilai tukar dapat menyebabkan pergerakan harga saham (Dornbusch dan Fisher, 1980).

Nilai tukar rupiah terutama terhadap dollar AS merupakan salah satu faktor penting bagi perkembangan dunia usaha. Fluktuasi nilai tukar yang berlebihan (over fluctuation) merupakan kendala operasional yang cukup dicermati oleh para pengusaha, karena di dunia usaha kestabilan dan kepastian memudahkan perencanaan usaha dan investasi. Pendekatan moneter menjadi utama di tahun 1970-an. Diketahui bahwa perubahan nilai tukar mempengaruhi indeks harga konsumen (Mussa, 1984). Perubahan indeks harga konsumen akan berdampak pada kondisi perekonomian secara umum, khususnya daya beli masyarakat. Daya beli masyarakat akan mempengaruhi kesempatan berinvestasi, 
termasuk investasi di reksadana. Sarno dan Taylor (2002) menjelaskan bahwa peran nilai tukar meningkat secara signifikan terutama dengan dikeluarkannya mata uang Euro dan munculnya sejumlah krisis mata uang beberapa waktu terakhir.

Kondisi tingkat suku bunga deposito dan tabungan di Indonesia relatif rendah pada tahun 2013an. Pada umumnya jika suku bunga bank tinggi maka masyarakat akan tertarik menanamkan dananya di bank dan sebaliknya apabila bunga bank rendah. Oleh karena itu jika suku bunga bank relatif rendah, masyarakat akan memilih intrumen investasi di luar pasar uang, misalnya reksadana. Jakarta Interbank Offered Rate (JIBOR) adalah suku bunga indikasi penawaran dalam transaksi PUAB (Pasar Uang Antar Bank) di Indonesia. JIBOR ditentukan berdasarkan tingkat bunga deposito berjangka rata-rata dari sejumlah bank (bank pemerintah, bank swasta nasional, dan bank asing) yang dianggap sebagai refleksi tingkat bunga pasar di pasar uang Jakarta. JIBOR terdiri atas 2 mata uang yakni IDR dan USD, dengan masing-masing terdiri dari 6 tenor yakni 1 hari, 1 minggu, 1 bulan, 3 bulan, 6 bulan dan 12 bulan (Siamat, 2001). JIBOR merupakan rata-rata dari suku bunga indikasi pinjaman tanpa agunan (unsecured) yang ditawarkan dan dimaksudkan untuk ditransaksikan oleh Bank Kontributor kepada Bank Kontributor lain untuk meminjamkan rupiah untuk tenor tertentu di Indonesia (Bank Indonesia, 2013).

Reksadana campuran sebagai salah satu jenis reksadana biasanya menempatkan instrumen investasinya pada obligasi. Obligasi merupakan salah satu intrumen di pasar modal. Investor yang menanamkan investasi pada obligasi memerlukan benchmark untuk menilai kinerja obligasi. Manajemen BEI sebagai pengelola pasar modal mengeluarkan indeks obligasi, salah satunya adalah Indonesian Government Bond Index (IGBX). IGBX diharapkan menjadi barometer dalam perdagangan obligasi negara sekaligus sebagai benchmark dalam mengukur kinerja obligasi secara keseluruhan.

Indeks Obligasi Negara adalah nilai rata-rata tertimbang (weigthed average) terhadap nilai obligasi yang masih tercatat dan dapat diperdagangkan. Perhitungan IGBX menggunakan metode perhitungan Bond Index yang lazim digunakan dengan berdasarkan perubahan harga pasar yang terjadi di pasar secara harian (dalam hal ini adalah data harga transaksi Obligasi Negara yang dilaporkan melalui PT Bursa Efek Indonesia selaku Penerima Laporan Transaksi Efek (BEI, 2010). IGBX dikelompokkan dalam beberapa sub-grup, di mana masing-masing sub grup terdiri atas beberapa Obligasi Negara yang memiliki struktur jatuh termpo lebih dari 1 tahun. Pengelompokan dilakukan berdasarkan uji statistik berdasarkan pada tingkat kemiripan setiap Time To Maturity (TTM).

Kerangka Pemikiran. Reksadana Campuran adalah reksadana yang melakukan investasi baik pada efek hutang maupun ekuitas dengan porsi alokasi yang lebih fleksibel. Atas dasar itu maka Reksadana Campuran mempunyai hubungan dengan IHSG karena adanya penempatan portofolio investasinya pada saham. Jika IHSG meningkat maka kinerja reksa dana diduga juga akan meningkat.

Jika terjadi depresiasi rupiah terhadap dollar, maka investor akan menangkap bahwa prospek perekonomian Indonesia suram dan kegiatan investasi pun akan menurun. Sebaliknya apabila terjadi apresiasi rupiah terhadap dollar ini maka kondisi ini akan meningkatkan ekspektasi dalam berinvestasi, termasuk investasi di reksadana. Dengan demikian apresiasi rupiah akan meningkatkan permintaan terhadap reksadana, akibatnya kinerja reksadana juga akan meningkat, dan sebaliknya. Jadi semakin tinggi nilai tukar dolar AS terhadap rupiah, semakin rendah kinerja reksadana. 


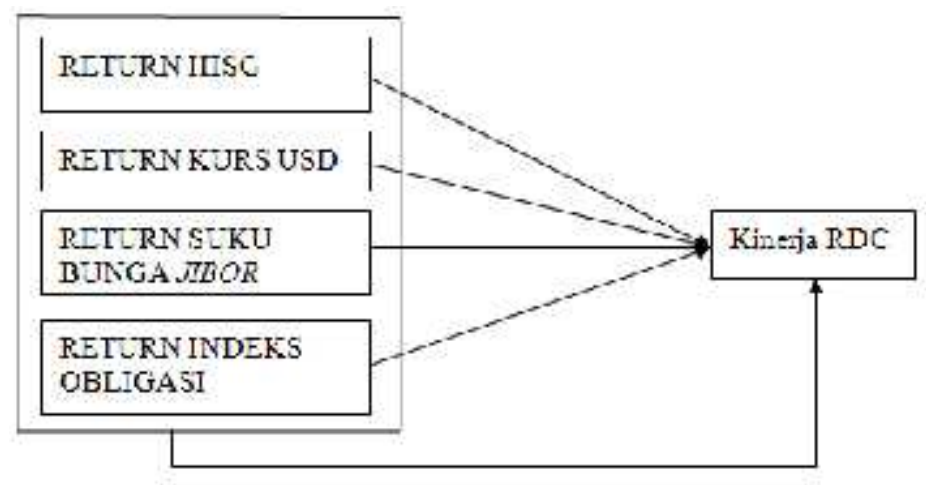

Gambar 1. Kerangka Pemikiran

Makin tinggi suku bunga JIBOR menyebabkan keinginan investor untuk melakukan investasi di bentuk investasi lain semakin kecil. Sebaliknya makin rendah suku bunga maka investor akan terdorong untuk melakukan investasi di bentuk lain, termasuk reksadana. Jadi makin rendah suku bunga akan meningkatkan permintaan terhadap reksadana, yang berarti semakin tinggi kinerja reksadana.

Indeks Obligasi (IGBX) merupakan indikator pergerakan harga obligasi. Sedangkan Reksadana Campuran merupakan reksadana yang berinvestasi pada kombinasi efek hutang, efek pasar uang, dan efek saham dalam proporsi dan prosentase tertentu secara dinamis. Oleh karena itu kenaikan indeks obligasi akan berpengaruh terhadap NAB Reksadana Campuran. Semakin tinggi IGBX, semakin tinggi kinerja reksadana

\section{Hipotesis Penelitian}

H0: Return IHSG, Return Kurs USD, Return Suku Bunga JIBOR dan Return Indeks Obligasi Negara secara bersama-sama berpengaruh terhadap kinerja Reksadana Campuran

H1: Return IHSG berpengaruh secara parsial terhadap kinerja Reksadana Campuran, ceteris paribus.

H2: Return Kurs USD berpengaruh secara parsial terhadap kinerja Reksadana Campuran, ceteris paribus

H3: Return Suku Bunga JIBOR berpengaruh secara parsial terhadap kinerja Reksadana Campuran, ceteris paribus

H4: Return Indeks Obligasi Negara berpengaruh secara parsial terhadap kinerja Reksadana Campuran, ceteris paribus

\section{METODE}

Penelitian ini merupakan penelitian kausal yang mengkaji beberapa faktor yang diduga memengaruhi kinerja reksadana campuran yang terdaftar di Bursa Efek Indonesia. Faktorfaktor tersebut antara lain Return IHSG, Return Kurs USD, Return Suku Bunga JIBOR, dan Return Indeks Obligasi Negara. Data yang digunakan adalah data harian pada periode 2 Januari 2012 sampai dengan 28 Desember 2012 (satu tahun hari bursa).

Kinerja reksadana diukur dari return yang dihasilkan. Return reksa dana dihitung dengan rumus sebagai berikut. 


$$
K i=\frac{N A B_{t}-N A B_{t-1}}{N A B_{t-1}}
$$

Keterangan: $\mathrm{Ri}=$ Tingkat pengembalian reksa dana; $\mathrm{NAB}_{\mathrm{t}}=$ Nilai Aktiva Bersih akhir; $\mathrm{NAB}_{\mathrm{t}-1}=$ Nilai Aktiva Bersih Awal

Return IHSG diukur dari perubahan IHSGt terhadap IHSG t-1. Return Kurs diukur dari perubahan KURSt terhadap KURSt-1. Return suku bunga JIBOR diukur dari perubahan suku bunga JIBORt terhadap suku bunga JIBORt-1. Return obligasi diukur dari perubahan Indeks Obligasi Negara (IGBX) saat ini dengan IGBX periode sebelumnya. Jadi seluruh variabel bebas diukur dengan rumus pertumbuhan sebagai berikut:

$$
\mathrm{RET}_{\mathrm{X}} \mathrm{X}_{\mathrm{i}}=\frac{\mathrm{X}_{\mathrm{i}, \mathrm{t}}-\mathrm{X}_{\mathrm{i}, \mathrm{t}-1}}{\mathrm{X}_{\mathrm{i}, \mathrm{t}-1}}
$$

Dimana: RET_Xi = return variabel bebas X, $\mathrm{i}=\mathrm{IHSG}$, KURS, JIBOR, IGBX; $\mathrm{X}_{\mathrm{i}, \mathrm{t}}$ $=$ nilai variabel bebas $\mathrm{X}$ untuk $\mathrm{i}=\mathrm{IHSG}$, KURS, JIBOR, IGBX pada waktu $\mathrm{t} ; \mathrm{X}_{\mathrm{i}, \mathrm{t}-1}$ = nilai variabel bebas X untuk $\mathrm{i}=\mathrm{IHSG}$, KURS, JIBOR, IGBX pada waktu t-1

Populasi dalam penelitian ini adalah reksadana campuran yang diperdagangkan di Bursa Efek Indonesia pada periode 2 Januari 2012 sampai dengan 28 Desember 2012. Sampel reksadana yang digunakan diambil dengan pendekatan purposive sampling. Kriteria-kriteria pengambilan sampel adalah sebagai berikut: 1) Reksadana campuran yang diperdagangkan dan terdaftar di BEI tanggal 2 Januari 2012 sampai dengan 28 Desember 2012 dan 2) Data lengkap tersedia dan bisa diakses oleh publik.

Jenis data yang digunakan dalam penelian ini adalah data sekunder yaitu IHSG, kurs tengah USD, suku bunga JIBOR rupiah jangka waktu 1 bulan, Indeks Obligasi Negara, dan data NAB/unit masing-masing reksadana campuran. Data IHSG dan IGBX diperoleh di website BEI. Kurs USD dan suku bunga JIBOR diperoleh di website BI dan data $\mathrm{NAB} /$ unit diperoleh di website www.infovesta.com.

Teknik analisis yang digunakan dalam penelitian ini adalah analisis regresi berganda. Regresi digunakan untuk memperkirakan secara kuantitatif pengaruh dari beberapa variabel bebas secara bersama-sama maupun secara parsial terhadap variabel terikat. Persamaan regresi yang digunakan adalah:

$$
Y=a+b 1 X 1+b 2 X 2+b 3 X 3+b 4 X 4+e
$$

dimana:

$\mathrm{Y}=$ Kinerja reksadana campuran (Kinerja RDC); $\mathrm{a}=$ konstanta; $\mathrm{b} 1, \mathrm{~b} 2, \mathrm{~b} 3, \mathrm{~b} 4=$ koefisien regresi; X1 = Return IHSG (RETIHSG); X2 = Return kurs USD (RETKURS); X3 = Return Suku bunga JIBOR (RETJIBOR); X4 =Return Indeks Obligasi (RETIGBX); $\mathrm{e}=$ error term.

Sebelum melakukan pengujian atas persamaan regresi yang diajukan, dilakukan pengujian asumsi klasik, yaitu normalitas, multikolinearitas, autokorelasi, dan heteroskedastisitas. Jika seluruh asumsi klasik telah dipenuhi baru dilakukan pengujian atas model persamaan regresi. Kesesuaian model regresi ditengarai dari besar nilai koefisien determinasi dan hasil uji F. Pengujian atas pengaruh variable bebas terhadap variable terikat dilakukan melalui uji t. 


\section{HASIL DAN PEMBAHASAN}

Statistik deskriptif atas variabel tergantung (Kinerja RDC) dan keempat variabel bebas disajikan pada Tabel 2. Berdasarkan statistik deskriptif tersebut diketahui bahwa rata-rata return harian Reksa dana Campuran (RDC) selama tahun 2012 adalah 0,032\%. Sementara selama satu tahun total return yang dihasilkan rata-rata adalah $7,8 \%$.

Tabel 2. Statistik Deskiptif Variabel-Variabel Penelitian

\begin{tabular}{lcccc}
\hline \multicolumn{1}{c}{ Variabel } & Min & Max & Mean & Std. Dev \\
\hline Kinerja Rdc (Total Return 1 Tahun & $-16,31$ & 26,48 & 7,8 & 7,03 \\
Return Ihsg & $-3,82$ & 3,32 & 0,055 & 0,86 \\
Return Kurs Usd & $-2,43$ & 1,40 & 0,024 & 0,35 \\
Return Suku Bunga Jibor & $-7,47$ & 1,75 & $-0,009$ & 0,66 \\
Return Indeks Obligasi Negara & $-3,12$ & 9,00 & 0,035 & 0,76 \\
\hline
\end{tabular}

Rata-rata return IHSG sebagai indikator portofolio pasar saham (bernilai 0,055) lebih tinggi daripada rata-rata return reksadana campuran. Kondisi pergerakan IHSG selama tahun 2012 yang mengalami pertumbuhan positif (bullish) menambah kepercayaan investor untuk menanamkan dananya pada efek saham. Pada awal tahun 2013 diketahui bahwa pergerakan IHSG cenderung menguat terbatas yaitu di atas 4.450. IHSG atau Indeks Harga Saham Gabungan seringkali dijadikan leading indicator siklus ekonomi negara yang bersangkutan. Hal ini disebabkan karena IHSG merupakan pergerakan seluruh harga saham yang tercatat di bursa (BEI).

Rata-rata return Kurs USD mempunyai rata-rata return yang positif (bernilai $0,024 \%)$. Berarti secara rata-rata rupiah mengalami depresiasi. Namun demikian return rata-rata Kurs USD lebih rendah daripada return RDC. Sejak awal tahun hingga akhir tahun 2012 pergerakan rupiah konsisten melemah. Pada 30 Desember 2011 rupiah berada di level 9.069. Posisi rupiah pada transaksi 28 Desember 2012 sore, berada di level 9.679. Pelemahan rupiah di sepanjang 2012 mencapai 6,7\%. Mengacu data Bloomberg, posisi terlemah rupiah terjadi pada 26 Desember 2012 yakni berada pada level 9.799. Posisi terkuat rupiah terjadi pada 25 Januari 2012, di mana rupiah berada di level 8.888.Jika dibandingkan dengan mata uang Asia lainnya, rupiah menjadi mata uang regional dengan performa terburuk pada tahun 2012. Sebagai perbandingan, won Korea Selatan berhasil menguat $7,65 \%$, peso Filipina menguat $6,9 \%$, dollar Singapura menguat $6 \%$, dollar Taiwan menguat $4,2 \%$, baht Thailand menguat $3,07 \%$, dan ringgit Malaysia menguat $3,48 \%$ pada periode yang sama (Taqiyyah dan Almawadi, 2013).

Rata-rata return Suku bunga JIBOR bernilai -0,009. Nilai ini lebih rendah daripada rata-rata return RDC bahkan memiliki rata-rata return negatif. Suku bunga JIBOR merupakan refleksi tingkat bunga pasar di pasar uang Jakarta. Nilai return suku bunga yang negative menunjukkan bahwa pada periode penelitian investasi di pasar uang kurang menguntungkan dibandingkan dengan investasi di reksadana campuran. Arah pergerakan suku bunga yang menurun mengakibatkan investor lebih suka menanamkan dananya di luar pasar uang.

Rata-rata Return Indeks Obligasi sebagai indikator pergerakan harga Obligasi Negara bernilai 0,035 . Nilai ini lebih tinggi dibandingkan nilai rata-rata return RDC. Hal ini sekilas menandakan bahwa investasi pada obligasi negara lebih menguntungkan bila 
dibandingkan dengan investasi pada RDC. Pergerakan indeks obligasi juga menandakan ke arah pertumbuhan yang positif.

Uji normalitas data menunjukkan data terdistribusi normal karena memiliki nilai Asymp. Sign di atas 0,05. Pengujian asumsi klasik menunjukkan data tidak mengalami multikolinearitas karena semua variabel bebas memiliki nilai tolerance di atas 0,1 dan nilai VIF kurang dari 5. Data juga bersifat homoskedastis karena nilai uji Glejser menunjukkan probabilitas signifikan semua variabel bebas di atas tingkat kepercayaan 0,05 . Data juga tidak mengalami autokorelasi karena nilai test Durbin-Watson $=1,903$, memenuhi persamaan $\mathrm{dU}<\mathrm{DW}<4-\mathrm{dU}$ (yaitu 1,60497 < 1,903 < 2,395). Dengan demikian model regresi yang dibentuk layak digunakan untuk menyelesaikan permasalahan penelitian ini.

Tabel 3. Pengaruh Variabel Makroekonomi terhadap Kinerja Reksadana Campuran, Tahun 2012

\begin{tabular}{|c|c|c|c|}
\hline Variabel & Koefisien & t hitung & Signifikansi \\
\hline Konstanta & $-0,002$ & $-0,322$ & 0,748 \\
\hline Return IHSG & 0,617 & 76,478 & $0,000 * * *$ \\
\hline Return Kurs USD & $-0,009$ & $-0,460$ & 0,646 \\
\hline Return Suku Bunga JIBOR & $-0,020$ & $-1,960$ & $0,051 *$ \\
\hline Return IGBX & 0,014 & 1,570 & 0,118 \\
\hline $\mathrm{R}^{2}$ & $96,2 \%$ & & \\
\hline Adj $R^{2}$ & $96,1 \%$ & & \\
\hline F hitung & 1.570 & & $0,000 * * *$ \\
\hline $\begin{array}{rrl}\text { Keterangan : } & * * * & \text { signifika } \\
& * * & \text { signifika } \\
& * & \text { signifika }\end{array}$ & $\begin{array}{l}=1 \% \\
=5 \% \\
=10 \%\end{array}$ & & \\
\hline
\end{tabular}

Data pada Tabel-3 menunjukkan hasil pengolahan data. Diketahui bahwa koefisien determinasi $\left(\mathrm{R}^{2}\right)$ bernilai 0,962. Hal ini berarti bahwa 96,2\% variasi Kinerja Reksadana Campuran bisa dijelaskan oleh variasi keempat variabel bebas (Return IHSG, Return Kurs USD, Return Suku Bunga JIBOR dan Return Indeks Obligasi). Selebihnya, yaitu 3,8\%, dijelaskan oleh sebab-sebab lain di luar model.

Uji $\mathrm{F}$ (F-Test) menunjukkan nilai $\mathrm{F}$ hitung sebesar 1.507 dengan tingkat probabilitas signifikansi sebesar 0,000. Nilai $\mathrm{F}$ hitung menunjukkan bahwa model yang dibentuk sesuai untuk menemukan bukti empiris pengaruh keempat variabel bebas terhadap kinerja reksadana campuran.

Persamaan regresi yang dihasilkan pada penelitian ini adalah sebagai berikut.

KRDC $=-0,002+0,617$ RETIHSG -0,009RETKURS $-0,020$ RETJIBOR $+0,014$ RETIGBX

Tabel 3 menunjukkan bahwa dari dua dari empat variabel bebas berpengaruh signifikan, yaitu Return IHSG dan return Suku Bunga JIBOR. Kedua variabel tersebut berturut-turut signifikansi pada $\alpha=1 \%$ dan $\alpha=5 \%$. Return Kurs USD berpengaruh negative namun tidak signifikan. Sementara Return IGBX berpengaruh positif, namun juga tidak signifikan.

Return IHSG merupakan variabel bebas yang paling besar pengaruhnya terhadap return reksa dana. Koefisien regresi variabel ini bernilai 0,617 signifikan pada $\alpha=1 \%$. Artinya setiap kenaikan 1 satuan Return IHSG, menyebabkan return RDC akan meningkat 0,617 satuan. 
Return Suku Bunga JIBOR memiliki koefisien regresi sebesar -0,021, signifikan pada $\alpha=10 \%$.. Berarti setiap kenaikan 1 satuan Return Suku Bunga JIBOR, maka return RDC akan turun sebesar 0,021 satuan.

Adanya pengaruh positif return IHSG terhadap kinerja reksadana campuran menandakan bahwa semakin baik kondisi investasi pada saham maka akan semakin baik pula kinerja reksadana campuran. IHSG menunjukkan indikator pergerakan harga saham di bursa efek. Harga saham yang meningkat menunjukkan bahwa saham yang diperdagangkan di bursa diminati pasar. Saham merupakan salah satu pembentuk reksadana campuran (RDC). Oleh karena itu, ketika IHSG meningkat, nilai RDC juga meningkat. Jika nilai RDC meningkat maka return RDC pun meningkat, yang berarti kinerjanya meningkat.

Hasil penelitian ini sejalan dengan hasil penelitian Pasha (2005), Kurnia (2005), Tamsul (2005), Sembiring (2007), serta Pasaribu dan Kowanda (2014). Para peneliti terdahulu menemukan pengaruh IHSG baik terhadap Nilai Aktiva Bersih/NAB (Pasha 2005, Tamsul 2005, dan Sembiring 2007) maupun terhadap tingkat pengembalian reksadana (Pasaribu dan Kowanda 2014) baik pada reksadana saham (Pasha 2005 serta Pasaribu dan Kowanda 2014), reksadana pendapatan tetap (Tamsul 2005), maupun reksanda campuran (Sembiring 2007).

Penelitian ini serupa dengan Chu (2011) di Hong Kong. Chu menemukan adanya hubungan kausal antara HSI (Hong Kong Index) dengan NAV (net asset values).

Sejauh ini belum ditemukan penelitian yang menggunakan variabel bebas Return Suku Bunga Pasar Uang Jakarta (JIBOR). Return JIBOR sebagai proxy dari return pasar uang, dapat dianggap serupa dengan SBI atau Suku Bunga Deposito. Temuan bahwa return JIBOR sebagai ukuran dari return pasar uang mempengaruhi kinerja reksadana sesuai dengan hasil penelitian Kurnia (2005) dan Tamsul (2005) yang mengatakan bahwa Suku Bunga Deposito berpengaruh negatif terhadap imbal hasil portofolio. Hasil penelitian ini juga sejalan dengan hasil penelitian Hamdan (2006) yang mengatakan bahwa NAB Reksa dana mempunyai hubungan negatif dengan tingkat SBI. Hubungan negative antara return suku bunga JIBOR dengan RDC menunjukkan bahwa kedua instrumen bersifat subsitutif. Ketika tingkat suku bunga JIBOR tinggi maka instrument ini menjadi lebih menarik bagi investor, dan berakibat investasi di RDC turun. Begitu pula sebaliknya.

Hasil penelitian ini berbeda dengan Chu (2011) yang menemukan bahwa Hong Kong Interbank Offer Rate (HIBOR) tidak memiliki hubungan kausal dengan NAV reksadana di Hong Kong. Hasil penelitian ini juga berbeda dengan hasil penelitian Shukla (2011) yang meneliti pengaruh variabel makroekonomi terhadap industri reksadana di India. Ditemukan pengaruh suku bunga positif dan signifikan terhadap industri reksadana. Tingkat bunga pada penelitian tersebut diukur dengan 10-year G-Securities interest rate.

Hasil penelitian ini mengenai pengaruh tingkat bunga pasar uang bertentangan dengan hasil penelitian Yoedistira (2007) dan Permata (2009) yang mengatakan bahwa Suku Bunga tidak berpengaruh terhadap NAB Reksadana. Perbedaan ini kemungkinan dikarenakan durasi data yang diambil peneliti sebelumnya adalah mulai tahun 1998 sampai dengan 2006. Kondisi perekonomian pada periode tersebut berbeda dengan kondisi sepanjang tahun 2012. SBI sejak tahun 1998 sampai dengan 2009 masih cukup tinggi, yang mengakibatkan rate deposito pasar uang antar bank juga masih tinggi. Rate SBI dan rate deposito bank-bank Jakarta selama tahun 2012 cukup rendah dan stabil, di 
mana SBI stabil di angka 5,75\% dan rata-rata bunga bank Jakarta berkisar antara 4,25\% p.a sampai dengan 5,25\% p.a di luar Special Rate (Bank Indonesia, 2013).

Hasil penelitian ini juga berbeda dengan hasil penelitian Nurdianti (2010), Ulinnuha (20140, serta Pasaribu dan Kowanda (2014). Nurdianti menemukan pengaruh SBI positif dan signifikan terhadap kinerja reksadana pendapatan tetap. Sementara penelitian Pasaribu dan Kowanda menemukan bahwa dari sepuluh reksadana saham terbaik pada tahun 2011, sembilan reksadana mendapatkan pengaruh positif tingkat bunga SBI terhadap tingkat pengembalian reksadana saham. Serupa dengan Pasaribu dan Kowanda, penelitian Ulinnuha (2014) juga menemukan pengaruh positif dan signifikan tingkat bunga Sertifikat Bank Indonesia terhadap reksadana campuran.

Pengaruh tingkat suku bunga pasar uang terhadap reksadana yang berbeda-beda, juga ditemukan pada penelitian Wibowo (2012). Pengujian Wibowo mengenai pengaruh tingkat suku bunga BI terhadap kinerja reksadana pendapatan tetap di Indonesia tahun 2005-2007, dilakukan secara parsial pada masing-masing tahun (2005, 2006, dan 2007) juga secara keseluruhan periode (2005-2007). Hasil penelitian menunjukkan bahwa pada tahun 2005 dan 2006 pengaruh suku bunga BI negatif dan signfikan terhadap kinerja reksadana pendapatan tetap. Sementara pengaruh suku bunga BI terhadap kinerja reksadana pendapatan tetap pada tahun 2007 positif namun tidak signifikan. Selanjutnya, pengaruh suku bunga BI terhadap kinerja reksadana pendapatan tetap secara keseluruhan tahun 2005-2007 positif dan signfikan. Berarti di Indonesia suku bunga BI yang merupakan instrumen pasar uang dan reksadana yang merupakan instrumen pasar modal dapat bersifat substitutif maupun komplementer.

Penelitian ini menemukan bahwa pengaruh kurs USD terhadap kinerja reksadana campuran tidak signifikan. Hal ini menandakan bahwa naik turunnya Kurs USD tidak mempengaruhi minat investor menanamkan dananya pada instrumen reksadana campuran.

Depresiasi rupiah tidak diikuti perubahan portofolio investasi, khususnya investasi di rekasadana. Kemungkinan investor reksadana, tidak mempertimbangkan return dari kurs ketika melakukan investasi di reksadana campuran. Dengan demikian ketika rupiah mengalami perubahan nilai tukar (terhadap USD khususnya), hal tersebut tidak mempengaruhi investor. Sebagaimana dijelaskan Sarno dan Taylor (2002) bahwa peran nilai tukar meningkat secara signifikan ketika muncul krisis mata uang. Pelemahan rupiah yang terjadi pada tahun 2012 tidak tergolong kondisi krisis.

Hasil penelitian ini didukung oleh Permata (2009) yang menemukan bahwa nilai tukar USD tidak berpengaruh signifikan terhadap nilai aktiva bersih reksadana pendapatan tetap dan Ulinnuha (2014) yang menemukan bahwa nilai tukar USD tidak berpengaruh signifikan terhadap nilai aktiva bersih reksadana campuran.

Namun demikian, temuan pengaruh Kurs USD pada penelitian ini tidak sejalan dengan Yoedistira (2007) dan Permatasari (2014). Yoedistira (2007) menyatakan bahwa nilai tukar rupiah terhadap dolar berpengaruh terhadap nilai aktiva bersih reksadana di Indonesia. Yoedistira mengunakan data periode 1998 sampai dengan 2006 di mana terjadi gejolak politik reformasi yang terjadi pada tahun 1998, yang menyebabkan nilai Kurs USD mencapai nilai di atas Rp.14.000,-. Permatasari (2014) menemukan bahwa meningkatnya nilai tukar USD terhadap rupiah menyebabkan kinerja reksadana pendapatan tetap turun. Penelitian Permatasari dilakukan terhadap 39 reksadana pendapatan tetap pada periode 2010-2012. Penelitian ini juga berbeda dengan hasil penelitian Monjazeb dan Ramazanpour (2013) yang menemukan pengaruh nilai tukar positif dan signifikan terhadap return reksadana di Iran.. 
Pengaruh return IGBX terhadap return reksadana campuran pada penelitian ini tidak signifikan. Pergerakan indeks obligasi relatif stabil meskipun pada bulan Februari 2012 mengalami kenaikan yang tajam (sampai menyentuh angka 143,93) dan menurun kembali setelahnya ternyata tidak mempengaruhi kinerja reksadana campuran. Pergerakan indeks obligasi yang relatif stabil menyebabkan volatilitasnya rendah, sehingga dampaknya terhadap perubahan return reksadana menjadi tidak nyata. Kemungkinan lain, prosentase investasi reksadana campuran dalam bentuk obligasi relatif kecil. Dengan demikian return obligasi tidak nyata berpengaruh terhadap return reksadana campuran.

Indeks Obligasi lebih mempengaruhi investor maupun Manajer Investasi pada reksadana pendapatan tetap sebagaimana ditemukan dalam penelitian Permata, 2009. Reksadana pendapatan tetap memang sebagian besar dananya ditanamkan dalam bentuk instrumen obligasi.

\section{PENUTUP}

Simpulan. Return IHSG, Return Kurs USD, Return Suku Bunga JIBOR dan Return Indeks Obligasi Negara secara bersama-sama (simultan) berpengaruh secara signifikan terhadap kinerja Reksadana Campuran. Secara parsial Return IHSG berpengaruh positif dan signifikan terhadap Kinerja Reksadana Campuran. Pengaruh Return Suku Bunga JIBOR terhadap kinerja Reksadana Campuran negatif dan signifikan. Pengaruh return Kurs USD dan Return Indeks Obligasi Negara tidak signifikan terhadap Kinerja Reksa dana Campuran. Return IHSG merupakan variabel yang paling besar pengaruhnya terhadap kinerja Reksadana Campuran.

Pergerakan Nilai Kurs USD terhadap rupiah yang tidak terlalu fluktuatif meskipun mengalami pelemahan secara perlahan tidak mempengaruhi kinerja reksadana campuran. Demikian juga dengan Indeks Obligasi Negara sebagai indikator pergerakan harga obligasi negara. Meskipun reksa dana campuran menginvestasikan dana pengelolaannya pada efek pasar uang bervaluta asing maupun obligasi, kedua variabel tersebut pengaruhnya tidak signifikan terhadap kinerja reksa dana campuran.

Investor, calon investor, maupun Manajer Investasi, dalam mengambil keputusan investasinya sebaiknya mempertimbangkan faktor makro ekonomi yang terjadi di pasar modal. Mengacu penelitian ini, dua hal yang perlu diperhatikan investor dan calon investor reksadana campuran adalah Return IHSG dan Return Suku Bunga JIBOR. Perhatian lebih besar perlu diberikan terhadap IHSG, karena koefisien regresinya paling besar. Jika Return IHSG naik maka kinerja reksa dana campuran pun akan naik, dan sebaliknya. Sebaliknya, jika Return Suku Bunga JIBOR naik, maka kinerja reksadana campuran akan menurun. Saran lain bagi investor adalah di saat kinerja Reksadana Campuran diprediksi akan naik, di situlah saat yang tepat untuk melakukan investasi pada produk reksa dana ini.

Model penelitian yang digunakan pada penelitian ini dapat digunakan peneliti yang akan datang untuk menemukan pengaruh variabel bebas yang sama pada penelitian ini terhadap jenis reksadana lainnya. Dapat pula dilakukan penelitian terhadap reksadana campuran, namun dengan mengubah variabel bebas yang diduga mempengaruhi. Misalnya saja diteliti pengaruh tingkat pertumbuhan ekonomi.

Pada penelitian ini pengaruh return kurs USD dan return IGBX terhadap return reksadana campuran ditemukan tidak signifikan terhadap data harian pada tahun 2012. Penelitian yang akan datang dapat menggunakan periode penelitian berbeda sehingga 
kemungkinan akan menemukan hasil penelitian berbeda. Alternatif lain, dapat dicoba penggunaan data mingguan atau bulanan terhadap model penelitian yang digunakan pada penelitian ini. Dash dan Kumar (2008) menggunakan data return mingguan untuk mempelajari pengaruh variable makroekonomi terhadap reksadana di India

Saran. Bagi peneliti yang akan datang, penelitian mengenai reksadana dapat dilakukan untuk menemukan perbedaan kinerja beberapa jenis reksadana berbeda. Hasil penelitian perbedaan kinerja reksadana jenis berbeda akan memberikan informasi bagi investor, terutama investor yang memerlukan masukan untuk memilih jenis reksadana untuk portofolio investasinya.

\section{DAFTAR RUJUKAN}

Alwi. Iskandar Z. (2005) Pasar Modal: Teori dan Aplikasi. Yayasan Pancur Siwah. Jakarta.

Bhattacharya, Rudrani; Ila Patnaik, dan Madhavi Pundit. (2013) "Emerging Economy Business Cycles: Financial Integration \& terms of Trade shocks". IMF Working Paper WP/13/119.

Bodie, Ziw; Alex Kane, dan Alan J. Marcus. (2012) Essentials of Investment $9^{\text {th }}$ Edition. Amazon.

BankIndonesia. (2013) "Moneter". http://www.bi.go.id/id/moneter/jibor/tentang/Contents/

BEI. 2010. Reksadana. http://www.idx.co.id/id$\mathrm{id} /$ beranda/produkdanlayanan/reksadana.aspx

Chu, Patrick Kuok-Kun. (2011) "Relationship between macroeconomic variables and net asset values (NAV) of equity funds: Cointegration evidence and vector error correction model of the Hong Kong Mandatory Provident Funds (MPFs)". Journal of International Financial Markets, Institutions \& Money. Elsevier doi: 10.1016/j.intfin.2011.06.003

Dash, Mihir dan Dinesh Kumar G. (2008) "A Study on the Effect of Macroeconomic Variables on Indian Mutual Funds". Social Science Electronic Publishing, Inc. http://ssrn.com/abstract=1316442

Departemen Keuangan RI. (2008) "Identifikasi Pemodal Asing di Pasar Modal Indonesia". Laporan Studi. Badan Pengawas pasar Modal dan Lembaga Keuangan. Jakarta

Dominic, Salvator. (2007) Ekonomi Internasional. Penerbit Erlangga. Jakarta.

Dornbusch, Rudiger dan Stanley Fischer. (1980) "Exchange Rate and The Current Account". The American Economic Review. Vol 70 Issue 5 (Dec 1980) pp 960-071

Grevina, Susan, (2013) "Cara Berinvestasi Reksa Dana". www.sam.co.id (diunduh pada Desember 2013)

Halim, Abdul. (2003) Analisis Investasi. Salemba Empat. Jakarta

Hamdan, R. (2006) Pengaruh SBI terhadap Perekonomian Indonesia. Karya Ilmiah : http : //www.binasolusi.blog.com/ Pengaruh SBI.

Kurnia, Ridiani. (2005) "Perkembangan Reksadana", Publikasi. www.bapepam.go.id

Madura, J. (2000) International Financial Management $6^{\text {th }}$ edition. South Western College Publisher. Cincinnati

Monjazeb, Mohammadreza dan Esmaeel Ramazanpour. (2013) "The Effect of Economic Factors on The Efficiency of Mutual Funds in Iran Seyedeh Javaneh Ahmadi Tulamy". Technical Journal of Engineering and Applied Sciences 3(15):1707-1711 
Mussa, Michael L. (1984) "The Exchange Rate Theory and Practice". University of Chicago Press. ISBN 0-226-05096-3 http://www.nber.org/books

Nurdianti, Hastri. (2010) "Analisis Pengaurh IHSG, SBI, Kurs, PDB, dan Inflasi terhadap Kinerja Reksadana Pendapatan Tetap". Skripsi Jurusan Manajemen Fakultas Ekonomi dan Ilmu Sosial. UIN Syarif Hidayatullah. Jakarta

Pasaribu, Rowland Bismark F dan Dyonysia Kowanda. (2014) "Pengaruh Suku Bunga SBI, Tingkat Inflasi, IHSG, dan Bursa Asing terhadap Tingkat Pengembalian Reksadana Saham”. Jurnal Akuntansi dan Manajemen Volume 25 Nomor 1 April 2014 ISSN 0853-1259

Pasha, Dian Novianti. (2005) "Pengaruh Indeks Harga Saham Gabungan terhadap Nilai Aktiva Bersih Reksadana Saham”. Skripsi. Jurusan Manajemen Fakultas Ekonomi. UNIKOMPP. Bandung

Permata, Riza. (2009) “Analisis Pengaruh Indeks Obligasi, Sukubunga SBI, Inflasi, Nilai Kurs USD dan Harga Minyak Bumi terhadap Kinerja Nilai Aktiva Bersih Reksadana Pendapatan Tetap". Tesis. Program PascaSarjana UGM Yogyakarta.

Permatasari, Maria Indah. (2014) "Pengaruh Inflasi, Suku BUnga BI, Kurs USD, Pertumbuhan Ekonomi, dan Rasio Beban Operasional terhadap Kinerja Reksadana Tetap di Pasar Modal Indonesia”. Jurnal Ilmiah Universitas Bakrie Vol 2 (05) 2014.

Pertiwi, Ginatu. (2013) "Kenapa Perlu Reksa Dana Campuran?” IndoPremier Investment. https://premierinvestments.files.wordpress.com.

Pratomo, Eko Priyo dan Ubaidillah Nugroho. (2004) Reksadana: Solusi Perencanaan Invetasi di Era Moderen. Gramedia Pustaka Utama. Jakarta

Rahmawati, Setya Ayu. (2009) "Pengaruh Variabel Indeks Suku Bunga SBI, Kurs Nilai Tukar, Harga Minyak Dunia, dan Tingkat Inflasi terhadap Kinerja Reksadana Pendapatan Tetap". Skripsi Jurusan Akuntansi Fakultas Ekonomi Universitas Brawijaya. Malang.

Ross, Stephen. (1976) The Arbitrage Theory of Capital Asset Pricing", Journal of Economic Theory. 13, 341-360.

Sarno, Lucio dan Mark P. Taylor. (2002) The Economics of Exchange Rates. Cambridge University Press. Cambridge. England.

Sembiring, Ferikawita M. (2007) "Pengaruh Perubahan Indeks Harga Saham Gabungan (IHSG), Tingkat Bunga Obligasi Pemerintah, dan Tingkat Bunga Sertifikat Bank Indonesia (SBI) terhadap Nilai Aktiva Bersih Reksa Dana Campuran", ejournal.kopertis4.or.id

Shukla, Sachchidanand. (2011) "Role of Macroeconomic Variables in Indian Mutual Fund Industry", Analytique Vol VII No 8 Jan-Mar 2011 pp 4-13

Siamat, Dahlan. (2001) Manajemen Lembaga Keuangan, Lembaga Penerbit FEUI. Jakarta Silitonga, Desmon. 2010 "Memilih Investasi Reksa Dana Tahun 2010", Artikel Reksa Dana BAPEPAMLK. www.aria.bapepam.go.id

Tamsul, S. (2005) Hubungan Antara Tingkat Suku Bunga Deposito dan Indeks Harga Saham Gabungan dengan Nilai Aktiva Bersih (NAB) Reksadana Pendapatan Tetap. Karya Akhir. Program Sarjana UI Jakarta.

Tandelilin, Eduardus. (2001) Analisis Investasi dan Manajemen Portofolio. Edisi Pertama. BPFE. Yogyakarta.

Taqiyyah, Barratut dan Issa Almawadi. (2013) "Performa Rupiah di 2012 Terburuk di Asia", Fokus. www.fokus.kontan.co.id 
Ulinnuha, Ahmad. (2014) "Pengaruh Indeks Harga Saham Gabungan, Nilai Tukar Rupiah, dan Sertifikat Bank Indinesia terhadap Nilai Aktiva Bersih Reksadana Campuran pada PT Manulife Aset Manajemen Indonesia", Skripsi Fakultas Ekonomi Universitas Jember. Jember.

Wibowo, Andi. (2011) "Pengaruh Variabel Makroekonomi terhadap Kinerja Reksadana Pendapatan etap di Indonesai”, Jurnal Akuntansi, Manajemen, Bisnis dan Sektor Publik, Volume 7 (2) Feb 2012: 163-182.

Yoedistira, M. Kharisma. (2007) Analisis Faktor - Faktor yang mempengaruhi Nilai Aktiva Bersih Reksadana di Indonesia 1998:1-2006:1. Tesis. Magister Ekonomika Pembangunan Program Pasca Sarjana UGM. Yogyakarta. 